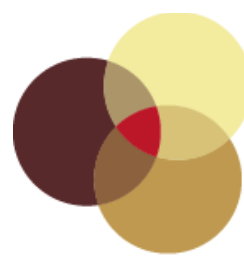

\title{
Nostalgia and La Jetée
}

\author{
Karla Huebner
}

\begin{abstract}
This essay contemplates Chris Marker's film La Jetée (1962) via Svetlana Boym's conceptualization of "restorative" versus "reflective" nostalgia. It looks in part at the film's presentation of the protagonist's restorative nostalgia, but unlike previous examinations of nostalgia's role in La Jetée, this essay foregrounds the viewer's own experience of a reflective nostalgia for the film. The author considers her personal and subjective, and historically specific, encounters with $L a$ Jetée in relation to how the film may produce a similar nostalgia in others through its storytelling and unusual combination of photographic and cinematic form. Drawing also on Réda Bensmaïa's semiotic and psychoanalytic analysis of the film's "pictogrammatic" quality, the essay further considers the possible roles of trauma and masochism in the film and for its viewers, and relates the experience of watching La Jetée to that of watching An Occurrence at Owl Creek Bridge (also 1962). The essay therefore situates both films in the context of historically situated yet ever-changing lived experience.
\end{abstract}

\section{About the Author}

Karla Huebner is Associate Professor of Art History and Affiliate Faculty in Women, Gender, and Sexuality Studies at Wright State University in Dayton, Ohio. She received her Ph.D. in the History of Art and Architecture from the University of Pittsburgh and her M.A. from American University in Washington, DC. Her research areas include surrealism, women artists, the history of gender and sexuality, and Czech modernism from 1890-1950. 


\section{Nostalgia and La Jetée}

Once upon a time, in the school year of 1968-69 to be precise, a group of children were sent from their own classroom to join another class for a film. They were going to see a film about Harriet Tubman, who as everyone knew or ought to have known was a famous conductor on the Underground Railroad. And so they saw the film on Harriet Tubman, which depicted her bravely stealing her charges away to freedom despite episodes of narcolepsy caused by a mysterious star-shaped wound on her forehead. Harriet Tubman was tough and did whatever she had to to save her runaway slaves; if necessary, she drugged babies to keep them from crying.

But for some reason a second film had been sent along with the Tubman film. Had it been requested, or was it an odd sort of bonus from the film company? If there was any explanation by either of the teachers, it went out the window and was lost on the playground; perhaps the explanation floated out across the asphalt and twined itself around the wooden fort where certain children in the group spent lunch-hours pretending to be castaways bitten by poisonous snakes, or knights on horseback, or researchers of magic and spirits. In any case, the teachers put on the second film. Black-and-white, like Tubman. That was normal enough for school films in those days. Only animated films arrived in color. Thus: first came a long gray shot of parked airplanes; there was a curious buzzing that could gradually be identified as the whine of engines. Then, ever so gradually, the buzzing was overlaid with the sound of a chorus: the Russian Liturgy of the Good Saturday, not that anyone in the room could have named this piece. A man's voice began to speak calmly in French-was there more than one child in attendance who recognized the sound of French?and words came onto a black screen:

"This is the story of a man, marked by an image from his childhood. The violent scene that upset him, and whose meaning he was to grasp only years later, happened on the main jetty at Orly, the Paris airport, sometime before the outbreak of World War III."

Quite some time later, in the school year of 1980-81 to be more precise (we could even be so precise as to specify Fall Quarter of 1980, although not, from our vantage point in the twenty-first century, the exact day), a pair of college students stood talking outside the remarkably ugly concrete building in which their film class met. They were taking the class because it was required of all theater majors-they had put it off until their senior year-but they confessed that they liked it. And as they stood talking, one of them grew strangely nostalgic. There was a film she had seen in school, she said, back when she was in fourth grade. It had been a very peculiar film, not the kind of thing one normally saw in grade school, but a sort of a science fiction film about a man in the future who was haunted by an incomprehensible childhood memory. For some reason it had always stuck in her mind as her own kind of incomprehensible childhood memory; she had always wondered if she would ever see it again. Her companion said it sounded interesting and that she probably would get to see it again someday, if she watched enough movies. She was less certain; the world was full of movies and how would she identify it? As it happened, the next film they saw in class was La Jetée.

Nostalgia is not usually so promptly-what? Answered? Cured? Resolved? as one could argue happened in this case. A psychoanalyst would probably suggest that the title La Jetée had always lurked in the student's subconscious and that the sight of it on the syllabus had prompted renewed nostalgia for the film, but while this is probably true, it merely explains the synchronicity of that particular moment of longing for La Jetée, not the fact of twelve 
years' worth of intermittently remembering and longing for a film about trauma, memory, desire, and death.

Nostalgia, as Svetlana Boym reminds us, "is a longing for a home that no longer exists or has never existed. ${ }^{\prime 1}$ Boym has proposed that there are two forms of nostalgia: the first, restorative nostalgia, "attempts a transhistorical reconstruction of the lost home" and "does not think of itself as nostalgia" (she focuses on the postcommunist experience), while reflective nostalgia thrives in the longing itself. ${ }^{2}$ In this essay, I ponder both in relation to $L a$ Jetée. Perhaps it was absurdly precocious of me to experience a nostalgic longing (a reflective one, in Boym's typology) when I wasn't even an adult, and for a film that most people wouldn't have thought to screen for a room of seven-to-ten year olds. But I did, and while La Jetée certainly wasn't the only thing that provoked for me a prematurely Proustian sense of longing, loss, wonder, and temps perdus, it prompted a different variety of this than did memories of things I had done or eaten or even watched on TV. The nostalgia I could or might even now experience at the recollection of watching reruns of My Friend Flicka or Lassie (or even, heaven forbid, the dismally didactic dramas on The Lutheran Hour) is qualitatively different than the haunting nostalgia of recollecting La Jetée, even if we rightly distinguish between the mystic and unsatisfied nostalgia for an unknown film incompletely recalled, and the later nostalgia for a known quantity which can be seen in film classes or even at will on bad videotapes or DVDs. The ache for a film, story, or work of music may be simple or complex, mild or intense; it may be easily sated by reacquaintance, or it may not. And here I argue that the complex, intense variety of nostalgia prompted by La Jetée is prompted by the inherent qualities of the film itself. A nostalgia for watching episodes of Lassie would doubtless be indicative of a personal attachment to the dog, or to the show's place in one's childhood routine, but probably not to anything inherent in the show's story or structure (despite the fact that Lassie always rescued someone). La Jetée, on the other hand, presents a story of trauma, memory, longing, and loss in a quiet and understated format that catalyzes the viewer in a way that a more active presentation might not. As Réda Bensmaïa puts it, the experience of the film goes beyond its formal qualities; "something comes over us that goes above and beyond any representation, something perhaps on the order of the subliminal." 3

But why?

Something strange occurs when a film about a man haunted by memory can itself haunt the memory of its viewers, for surely not every story on this theme causes its readers or viewers to react thus. For that matter, perhaps not every era encourages such a reaction. Just as nostalgia itself has arisen differently and been treated differently at different times (Boym notes that it was once treated as a disease), ${ }^{4}$ so perhaps the type of story told here provokes different reactions among viewers who first see it at different historical moments. People who, like me, first saw La Jetée during the Cold War tend to share a deep fondness for it. Yet a friend of mine who enjoys science fiction and philosophical topics, and who like me grew up during the Cold War, saw La Jetée for the first time in the early 2000s and

\footnotetext{
${ }^{1}$ Svetlana Boym, The Future of Nostalgia (New York: Basic Books, 2001), xiii.

2 Ibid., xviii.

${ }^{3}$ Réda Bensmaïa, "From the Photogram to the Pictogram: On Chris Marker's La Jetée," Camera Obscura 24 (1990): 144. Emphasis original.

${ }^{4}$ Boym, The Future of Nostalgia, xviii; 3-18.
} 
described it as merely "okay." Was this just him or is this typical of people who encounter the film in the twenty-first century? (I have no answer for that, I merely pose the question.)

Boym observes that "[t]he twentieth century began with a futuristic utopia and ended with nostalgia." Optimism about the future was "discarded... sometime in the $1960 \mathrm{s.}{ }^{\prime 5}$ We see this loss of optimism clearly in La Jetée; while it was hardly the first dystopian view of the future, we cannot help but note that it presents not only the post-World War III future as grim (who during the Cold War didn't envision an unlivable existence after World War III?) but also the "pacified" future. The protagonist cannot desire the future even when it is offered to him as a means of survival, for his nostalgia is too strong. He refuses to see anything desirable about the future, for he sees it entirely as a product of the hideous postcatastrophic time from which he time-travels.

At the time La Jetée was made, Cold War anxiety was surely at its height. Children might feel excitement at the idea of living like the Jetsons and going to the moon, but adults experienced a world in which American couples honeymooned in backyard fallout shelters, magazines like Time and Life discussed whether the fallout-shelter haves would shoot the have-nots in time of need, and the Cuban Missile Crisis was the news of the day. By the time I first saw La Jetée, anxiety about nuclear war had partly given way to a more generalized angst prompted by Vietnam, Biafra, assassinations, hijackings, and demonstrations. Fears about the nature of the modern world and the future obsessed much of the globe. The protagonist of La Jetée might reject the future, but viewers of his story could simultaneously understand his desire for the past and find the calm, serious-but-faintly-smiling faces from the future appealing, almost godlike. To the viewer, the beings from the future might be rejectable not for being "pacified" but for possessing that godlike calm and certainty and knowledge that make mere humans feel abashed and imperfect-especially humans from the turbulent 1960s. Sander Lee, in his Platonic approach to La Jetée, observes that until we meet the inhabitants of the future, our protagonist is "the wisest person we've encountered." Now, he is "inferior" and must wear sunglasses "in the bright light of their wisdom" while they wear marks suggesting the Hindu third eye of contemplation and self-discovery. ${ }^{6}$

Marker in fact filmed La Jetée after experiencing two incidents of censorship by the French government. In 1953, the Marker-Resnais film Les Statues meurent aussi offended for its references to French colonialism, while the film immediately preceding La Jetée, the 1961 Cuba, si! was banned for its sympathetic view of the Cuban revolution. Thus Lee Hilliker connects La Jetée not just to Cold War bomb fears, but also to French colonial torture, and suggests that the assassin can be read as the censor. ${ }^{7}$

But let us return to Boym and nostalgia. Boym points to nostalgia as the "yearning for a different time-the time of our childhood, the slower rhythms of our dreams." ${ }^{8}$ The protagonist of La Jetée desires the moment from his childhood at Orly, for despite its traumatic violence, it is sweeter and more wonderful than anything else he knows. Though he saw a man (himself!) killed, he recalls the pleasure of the outing to the airport and the beauty of the woman's face. Indeed, had the trauma of seeing the killing not fixed the

\footnotetext{
${ }^{5}$ Svetlana Boym, The Future of Nostalgia, xiv.

${ }^{6}$ Sander Lee, "Platonic Themes in Chris Marker's La Jetée." Senses of Cinema, March, 2000, accessed June 20, 2015, http://sensesofcinema.com/2000/feature-articles/jetee/

7 Lee Hilliker, "The History of the Future in Paris: Chris Marker and Jean-Luc Godard in the 1960s," Film Criticism 24, (2000): 7, 11.

${ }^{8}$ Boym, The Future of Nostalgia, xv.
} 
moment in his mind, he might not remember the outing or the woman; no doubt there were other outings and other attractive faces in his childhood. Though we are nostalgic for happier times, we often best recall those that were bittersweet. Would I have remembered La Jetée with such poignant intensity had it been a cheery film or one like all the others we saw at school? Even the Harriet Tubman film was memorable in part because of its somber theme and gritty imagery.

For Boym, nostalgia is a "rebellion against the modern idea of time, the time of history and progress." She suggests that "[t]he nostalgic desires to obliterate history and turn it into private or collective mythology, to revisit time like space...." ${ }^{\prime 9}$ Certainly, La Jetée rebels against optimistic notions of history and progress; rather than the improvement of all things through progress ("better living through science"), La Jetée suggests that all "progress" brings is annihilation tempered by random cruel survivals. Our protagonist, the nostalgic, has every reason to want to obliterate history. History has rendered his past so limited that all it can be for him is a kind of private mythology. Further, when Boym suggests that nostalgia itself, with its "mourning of displacement and temporal irreversibility, is at the very core of the modern condition" ("a historical emotion," "coeval with modernity itself"), ${ }^{10}$ we can easily see La Jetée's protagonist as the modern Everyman who longs (in an extreme form) for les temps perdus.

Again as if writing with La Jetée in mind, Boym states that "[0]utbreaks of nostalgia often follow revolutions." While the World War III of the film is not a revolution, it produces an upheaval in which at least part of the population can only long for the past. And, of course, long "for the unrealized dreams of the past and visions of the future that became obsolete."11 Anything that our protagonist longed for as a child has been obliterated; the possibilities inherent in desires for love, toys, wisdom, growing-up-to-be-a, have all been destroyed.

And here, when Boym proposes that "nostalgia is about the relationship between individual biography and the biography of groups or nations, between personal and collective memory, ${ }^{\prime \prime 2}$ we find that this is starkly illustrated by La Jetée, which tells the story of an individual in light of and contrasted with his group or nation (we cannot be sure who his fellow survivors are), in which his individual memory may not be wholly alien to the collective memory, yet is entirely personal and far stronger than the memory of any other individual within the collective. He has shared the experience of World War III with his fellows, and therefore is representative of them, yet his individual memory of an earlier time means much more to him and therefore gives his captors the opportunity to use him for their own ostensibly altruistic purposes. As Hilliker observes, the technocrats use the imagemaker's understanding of the past to build their pacified future, first using the image, then killing it when it has served its purpose. ${ }^{13}$

But what of the film's effect on us? The recent growth of critical literature on La Jetée (and on Marker's work generally) suggests that the film continues to compel viewers, some

\footnotetext{
${ }^{9}$ Ibid., $\mathrm{xv}$.

${ }^{10}$ Ibid., xvi.

${ }^{11}$ Ibid., xvi.

${ }^{12}$ Ibid., xvi.

${ }^{13}$ Hilliker, "The History of the Future in Paris," 12.
} 
of whom were surely born well after it was made. ${ }^{14}$ How does it affect its audience and why does it subsequently provoke a nostalgic longing in some of us?

For Bensmaïa, some of La Jetée's capacity to produce intense emotion in the viewer resides in the "hallucinatory fascination" of the film's images, ${ }^{15}$ but also in the film's lacunae: in its wordless images, its fades to black, and the things that are not shown (such as the corpses of World War III). Bensmaïa speaks of "the experience... this film continues to produce even after we have seen it again and again." He inquires how we deal "with the extraordinary uncanniness-with the uneasiness and the fascination that continue to occupy our thoughts...."16 Here Bensmaïa illustrates Boym's idea of nostalgia as fundamentally ambivalent, "about the repetition of the unrepeatable, materialization of the immaterial, ${ }^{17}$ for like me, he reacts to his nostalgia about the film by watching it repeatedly and attempting to find the source or at least the mechanism of his fascination, and like me he observes the "striking... coalescence" between the representation (images) and the experience (affect) in this film. ${ }^{18}$

Bensmaïa separates the effects of the visual and auditory upon us, suggesting that at one level "we find ourselves with two narratives that are like one." To get "closer to what in La Jetée produces an enduring uneasiness"-to account for what "continues," in his opinion despite the narration, "to irradiate the almost 'mystical' atmosphere that emanates from this film"-he proposes approaching La Jetée via Piera Aulagnier's concept of the "pictogram." According to Aulagnier, "The space and the activity of the originary are different for us from the unconscious and from the primary processes. This activity has the property of metabolizing any affective experience present in the psyche into a pictogram that is, indissociably, representation of the affect and affect of the representation." This theory, Bensmaïa suggests, can help us understand how we respond to La Jetée's story yet are simultaneously kept "completely removed from it." ${ }^{19}$

In his strongly semiotic examination of La Jetée, Bensmaïa points to the "absence of indexing," in which "[i]mages escape from the text and no words are able to name them (for us)." He finds that "These images resemble 'confessions,' images that have more the look and the power of aborted actions than of speech. ${ }^{\prime 20}$ The nature of the extended dissolves and fades are of vital significance to him, as he argues that "the dissolves and the fades show us this thing we must blind ourselves to in order to be able to see," which is our repressed "representative core." 21 At the same time, Bensmaïa believes that "one can go beyond the paradox of saying that in the dissolves and fades it is possible to 'say' the

\footnotetext{
14 See for example Victor Burgin, The Remembered Film (London: Reaktion, 2004); Catherine Lupton, Chris Marker: Memories of the Future (London: Reaktion, 2005); Nora M. Alter, Chris Marker (Urbana and Chicago: University of Illinois Press, 2006); Sarah Cooper, Chris Marker (Manchester and New York: Manchester University Press, 2008); Janet Harbord, Chris Marker, La Jetée (London: Afterall Books, 2009), and various studies by Raymond Bellour.

15 Bensmaïa, "From the Photogram to the Pictogram," 147.

${ }^{16}$ Ibid., 142. Emphasis original.

17 Boym, The Future of Nostalgia, xvii.

18 Bensmaiia, "From the Photogram to the Pictogram," 144.

19 Ibid., 143-144, quoting Piera Aulagnier, La violence de l'interprétation : Du pictoramme à l'énoncé, $2^{\text {nd }}$ ed. (Paris : P.U.F., 1981), 77. Emphasis original.

${ }^{20}$ Ibid., 144. Emphasis original.

${ }^{21}$ Ibid., 145. Emphasis original.
} 
unspeakable and to 'see' the unrepresentable."22 One photographed body becomes another photographed body, or part of a body, or part of an object; in the absence of direct representations of human suffering, "these moments of intense fusion and/or tearing apart" are displaced onto the dissolves. ${ }^{23}$ That is, in these dissolves and fades, "these pictogrammatic signals-signs," images slowly merge and pull apart, providing us with metaphoric images of decomposition that combine with the explicit scenes of the ruined landscape to provide us with a complex imagery of pain and destruction. This displacement of violence onto the dissolves and fades, says Bensmaïa, is why these transitions are so lengthy-duration makes them legible. ${ }^{24}$ Laura Mulvey, who suggests that "the reality of the photograph as index becomes entwined with the problem of time," ${ }^{\prime 25}$ elaborates that "[t]he still photograph represents an unattached instant" while the moving image "cannot escape from duration, or from beginnings and ends...."26 It is worth noting that the sole moving image in the film, the grainy shot in which the woman opens her eyes, ${ }^{27}$ becomes obscured by the complexity of these transitions in the blurry video version, while its considerable length is ruthlessly condensed in the ciné-roman version, which presents it as two straightforward photos.

Bensmaïa suggests that image after image, along with voice and music, merge in a "surplus of information," to form a pictogram reflecting an unspeakable scene. He observes, "Like the film's protagonist, the spectator is not yet delirious, but s/he does experience 'the conflict which results from the desire for fusion and the desire for annihilation, love and hate, the activity of representation as a desire for the pleasure of being and a hate of having to desire. ${ }^{\prime \prime 28} \mathrm{He}$ concludes that through the film's "pictogrammic montage" we experience a Lacanian "FADING of the subject"-the dissipation of the subject, "the original nondifferentiation at the heart of psychosis." 29

Perhaps, but whether this constitutes the true core of our engagement with La Jetée is another question. What is it that we are drawn to repeat and perhaps master about a movie? Are we traumatized by the fades and dissolves and indeed the skillful pacing of the transitions, or do we respond more to the story itself, which Bensmaïa largely discounts as a separate and almost unrelated parallel narrative? Catherine Lupton points out that unlike most avant-garde films, La Jetée doesn't deny viewers the traditional pleasures of storytelling, fantasy, and "projected fulfillment of desire." ${ }^{30}$

\footnotetext{
22 Ibid., 144.

${ }^{23}$ Ibid., 149

${ }^{24}$ Ibid., 149, 152.

${ }^{25}$ Laura Mulvey, Death 24x a Second: Stillness and the Moving Image (London: Reaktion, 2006), 44.

${ }^{26}$ Mulvey, Death $24 x$ a Second, 13.

${ }^{27}$ This is explored in Bruce Kawin, "Time and Stasis in La Jetée," Film Quarterly 36 (Fall 1982): 15-20.

${ }^{28}$ Ibid., 156, quoting Piera Aulagnier, La violence de l'interprétation: Du pictogramme à l'énoncé, $2^{\text {nd }}$ ed. (Paris: P.U.F., 1981), 79. Emphasis original.

29 Ibid., 157. Claudine Frank notes Lacan's debt to Roger Caillois; see Roger Caillois, "Mimicry and Legendary Psychasthenia," in The Edge of Surrealism: A Roger Caillois Reader, ed. Claudine Frank, trans. Claudine Frank and Camille Naish (Duke University Press, 2003), 89-103.

${ }^{30}$ Lupton, Chris Marker, 94.
} 
Several scholars have noted that Marker called La Jetée a remake of Hitchcock's Vertigo; Victor Burgin calls our attention to the Hitchcock film's (and likewise La Jetée's) staging of Freud's dictum that "[t]he finding of an object is in fact a refinding of it." Burgin observes that not only are both films retellings of the Orpheus myth, but that La Jetée inverts the myth's above/below-ground placement of seeker and sought; instead of visiting Hades from the sunlit world, La Jetée's protagonist visits the sunlit world of the dead past from the hellish cave of the present. ${ }^{31}$

Burgin further connects La Jetée with George du Maurier's novel Peter Ibbetson (1891; filmed in 1935), in which a prisoner reunites with his beloved in shared lucid dreams. ${ }^{32}$ Burgin comments, however, that (unlike the active beloved in Peter Ibbetson) La Jetée's woman in the remembered image is "pure function," purely "that with which the man seeks to be (re)united;" the object in a poignant fort/da game. ${ }^{33}$ As the narrator tells us, "This face, which was to be the only image of peacetime to traverse the time of war, he long asked himself if he had really seen it; or if he had created this moment of gentleness to support the moment of madness which was to come." And here, I can't help being reminded of an image I once saw across the waiting area in an airport around the time I first saw La Jetée, of a beautiful, carefree young woman striding toward me. While the airport woman-in full color and lifesize or close to it-is not the only image of a lovely Sixties lass to inhabit my memory, the model's untroubled face and gait, so briefly glimpsed, had a very different effect than (for instance) the magazine Breck Girl ads with which I decorated my childhood bedroom. The airport photograph was in a sense my Gradiva (another literary figure that Burgin connects to the woman glimpsed in La Jetée ${ }^{34}$ )-always young, always beautiful in walking, always a potent symbol of the promise rather than the devastations of the 1960 s.

Did personal trauma prompt my attachment to La Jetée? While I can't say I ever considered myself to have been traumatized at the age of nine, it is true that my grandfather had just died and my family had then moved two thousand miles from everyone I knew. Perhaps this was more traumatic than I realized and I was able to recognize in a film my own buried loss. Or did I, unknowing, share the collective trauma of a bomb fear I barely knew existed? While my school years were largely devoid of nuclear angst, I had seen an unsettling television program about fallout shelters, which repeated all morning while I played on the floor and wondered what was going on-why were these people scurrying to the buildings with the familiar funny sign? Anxiety and trauma, even though not our own, are always memorable.

Thus, we return to Boym. In Boym's theorization of restorative versus reflective nostalgia, we must put our protagonist in the restorative camp. After all, he can hardly be called the wistful, ironic, homecoming-delaying creature of reflective nostalgia, although Boym so clearly prefers reflective to the often-nationalistic restorative nostalgia that she associates with "recent national and religious revivals." ${ }^{35}$ But how could our protagonist ever be a reflective nostalgic? Unlike Boym and the rest of us (at least, those in a position to read and watch films, not those displaced and starving in refugee camps), our protagonist does

\footnotetext{
${ }^{31}$ Burgin, The Remembered Film, 93, quoting Freud, 3 Essays, Standard Edition 7, 222.

32 Ibid., 100. Burgin also notes André Breton's attachment to Peter Ibbetson; I will add that the exiled Czech surrealist

Toyen produced an altar to Peter Ibbetson for the 1947 Surrealist exhibition.

33 Ibid., 99.

${ }^{34}$ Ibid., 92-93.

${ }^{35}$ Boym, The Future of Nostalgia, xviii.
} 
not live in a world filled with commercialized nostalgia, where people buy and sell Kewpie dolls, Victorian and fake-Victorian postcards, other people's family photos, Soviet army caps, and so-called "East German kitsch." Our protagonist hasn't fled Russia or Bosnia or Rwanda (all of which still exist), but survives a nuclear holocaust and lives in an underground prison camp with only one prewar memory to comfort himself (if comfort is a suitable concept for the memory of an assassination). While in day to day life we may prefer Boym's reflective nostalgia to restorative nostalgia, we can grant that the protagonist of La Jetée has no room to choose. How can his nostalgia be ironic? How can he be enamored of the distance between present and past? ${ }^{36} \mathrm{He}$ is lucky to have his nostalgia, restorative though it is, for it is clear that by possessing his one intense memory and a powerful nostalgia, he has more than most of the other survivors (viewers, on the other hand, can claim reflective nostalgia, exploring "ways of inhabiting many places at once and imagining different time zones"). ${ }^{37}$

At the same time, we should not discount the conclusion arrived at by Sander Lee in his Platonic interpretation of La Jetée, which is that the reason the man rejects the future and can be killed in the past (which has heretofore been posited as representing the Platonic realm of the real, which he alone can enter from the post-holocaust Cave) is that the "pacified" future is a Platonic realm of intellect cleansed of emotion and action, whereas the man is ultimately driven by passion and chooses instead to go to the realm of the appetites, a place readily accessible to the other inhabitants of the Cave (the assassin). For Lee, the story's poignancy lies in the protagonist's fatal flaw: "in the end he reduces himself to the level of his enemies when he chooses to discard the noble path offered to him by the future in order to wallow in a nostalgic illusion of adolescent romantic love. ${ }^{\prime 38}$ Perhaps the illusion of love is indeed part of why he chooses the past, but it does not explain how or why the film haunts its viewers.

Boym remarks that for Freud, "nostalgia was not a specific disease but a fundamental structure of human desire linked to the death drive"-that for him, one could only return home "through analysis and recognition of early traumas." ${ }^{39}$ Prompted by Freud's observation that "the pleasure principle seems actually to serve the death instincts," Leo Bersani asks whether the death instinct might be "erotogenic masochism. " 40 If the death instinct involves a desire to return from stimulation to stasis, then it's possible that the protagonist's "endless return to the scene of a suspended death" ${ }^{11}$ is both a repetitive response to trauma and a masochistic pleasure that builds and releases. But are we then masochistic? Is watching La Jetée a form of pleasurable torment?

I'm not sure that it is, at least not in the colloquial sense. Trauma need not lead to masochism, nor need masochism originate in trauma. But at this point I recall yet another childhood punctum (to steal a word from Barthes): the grade-school pleasure of watching An Occurrence at Owl Creek Bridge in reverse. I don't suppose I have ever repressed the recollection of our juvenile delight at watching the hanged man spring back to life and run

\footnotetext{
36 Ibid., 50.

37 Ibid., xviii.

${ }^{38}$ Lee, "Platonic Themes in Chris Marker's La Jetée."

${ }^{39}$ Boym, The Future of Nostalgia, 53-54.

${ }^{40}$ Leo Bersani, Baudelaire and Freud (Berkeley: University of California Press, 1977), 84 with reference to Freud, Beyond the Pleasure Principle in Standard Edition, 18; 63.

${ }^{41}$ Thanks are due to one of the anonymous reviewers for this formulation.
} 
backwards through the woods as the film rewound; we were filled with joy and laughed heartily at this comic effect. But what I had forgotten until now was that this was not my first encounter with the film (which I now-not being a film scholar but an art historian-discover to my surprise was based on an Ambrose Bierce story and filmed in France in the very same year as La Jetée). I had first seen Occurrence at Owl Creek Bridge during the same year that I first saw La Jetée-probably even on the same day. While I recognized Occurrence at Owl Creek Bridge when I saw it again the next year at a different school, the fact of the repeat fell out of my conscious memory, to be replaced by the recollection of its entertaining reversal. Was the initial recollection repressed or merely less memorable? Was the experience made re-memorable by reversing the film? Was Occurrence at Owl Creek Bridge-a story about a soldier executed in the Civil War-more traumatic viewing than La Jetée in a school year that began with the Warsaw Pact nations' invasion of Czechoslovakia and that continued with the immolations of Jan Palach and Jan Zajíc?

Mulvey has characterized Freudian trauma as "an event or experience that arouses too much psychic excitement for the subject to be able to translate its significance into words." She further suggests that trauma's marking of the unconscious produces "a kind of index of the psyche that parallels the photographic trace of an original event." ${ }^{\prime 2}$ She then considers the possibility, theorized by Peter Brooks, of narrative closure's parallel to the death drive, saying "Of all the means of achieving narrative stasis, death has a particular tautological appeal, a doubling of structure and content." ${ }^{\prime 43}$ Both La Jetée and Occurrence at Owl Creek Bridge provide this kind of fatal doubling. When we add repeated viewings to the mix, whether nostalgic or simply unexpected, the doublings multiply, perhaps multiplying trauma for the viewer or conversely perhaps providing mastery of trauma.

Boym states, appositely, "A cinematic image of nostalgia is a double exposure, or a superimposition of two images-of home and abroad, past and present, dream and everyday life." ${ }^{44}$ While I've always thought Occurrence at Owl Creek Bridge was haunting in its own way, I've never yearned for it, and have recalled it most clearly in reverse-a form of repetition that Bruce Kawin rightly suggests breaks a spell. ${ }^{45} \mathrm{~A}$ hanged man who runs in reverse from the arms of his wife, dashing backwards through the woods only to submerge himself and be jerked from the water to the bridge-gallows like a fish on a fishing pole, especially at a speed slightly faster than 24 frames per second, can hardly be traumaticlaughter dispels the tension created by his execution. In comparing photography and film, Mulvey posits that the "freezing of reality" that occurs in a still photograph "marks a transition from ...life to death" whereas "cinema reverses the process." 46 In this formulation, Owl Creek Bridge reverses direction more than once even without, but especially with, the intervention of the film run backwards. Certainly, in this respect Owl Creek Bridge differs dramatically from La Jetée despite the two films' similarly fatal endings. Owl Creek Bridge run in either direction has the "elusive," "insubstantial and irretrievable" quality Mulvey attributes to the medium of film, but La Jetée, though it somehow (despite its static images) shares these attributes when run normally, would be incomprehensible, not comic, run

\footnotetext{
${ }^{42}$ Mulvey, Death $24 x$ a Second, 65.

43 Ibid., 70-72.

${ }^{44}$ Boym, xiii-xiv.

45 Bruce F. Kawin, Telling It Again and Again: Repetition in Literature and Film, reprint, 1972 (Champaign, IL: Dalkey Archive Press, 2015), 82.

${ }^{46}$ Mulvey, Death $24 x$ a Second, 15.
} 
backward and it possesses, in part though its use of still photographs, what Mulvey calls their "heavy presence of passing time." ${ }^{147}$ Owl Creek Bridge also relies on cuts rather than on fades and dissolves-there is one apparent fade, significantly during the underwater sequence, but I believe there is only that one until the film's closing fade. Thus Owl Creek Bridge refuses or nearly refuses to displace death onto the screen's darkness except for at that crucial moment after the bound prisoner seemingly plummets deep into Owl Creek but actually drops toward death.

Both films encourage us to be "pensive spectators" who reflect on "the visibility of time in the cinema." ${ }^{48}$ They also encourage repeated viewing, which even if not tied to nostalgia is the mark of a good film and perhaps especially a "cult film. ${ }^{\prime 49}$ Indeed, Kawin calls repetition "fundamental to human experience." It can be compulsive and neurotic or spontaneous and freeing $;^{50}$ it can even be "key to our expression of experience. ${ }^{\prime 51}$ Kawin proclaims that "So long as we do not falsify our past with possession and fear and remembering, we can in the instants of repetition live both in the ordinary 'now' and in the 'then made now'transcending our life in space by discovering our freedom in time. ${ }^{152}$ For Kawin, the Proustian sensory and emotional recall of fragments is "an answer to death." 53

Was, then, my attachment to La Jetée solely a result of the film's genius? Or did it stick in my mind for darker reasons, resonating with personal trauma? How can we know? We can only speculate. As the film tells us, "[n]othing distinguishes memories from other moments: it is only later that they make themselves recognized by their scars."

In any case, La Jetée has always presented me with strange synchronicities: in the year 2002 a friend who didn't yet know I had ever seen it decided to give me his copy of La Jetée: ciné-roman. And as André Breton wrote in Nadja, "[w]ho am I? If for this once I were to rely on a proverb, then perhaps everything would amount to knowing whom I 'haunt.'"154

\footnotetext{
47 Ibid., 66.

48 Ibid., 11.

${ }^{49}$ Burgin notes in The Remembered Film that Marker called Vertigo "a cult film" and that so is La Jetée. Why is it important to state this? Because "A cult film is one that is viewed repeatedly" (108).

${ }^{50}$ Kawin, Telling It Again and Again, 5.

51 Ibid., 7-8.

52 Ibid., 85. Emphasis original.

53 Ibid., 86.

${ }^{54}$ André Breton, Nadja, trans. Richard Howard (New York: Grove Press, 1960), 12.
} 


\section{Acknowledgements:}

Thanks are due, chronologically, to the faculty of Eldorado School for the Gifted in Orange, California and to Mrs. Baker of Wagner Elementary in Placentia, California; to Bruce Kawin for teaching La Jetée during his year at UCSC; to Lucy Fischer at University of Pittsburgh for assigning the paper on nostalgia that became this essay; to John Smalley for the copy of La Jetée: ciné-roman; and to the anonymous reviewers for their suggestions. 
(cc) $\mathrm{EY}$

New articles in this journal are licensed under a Creative Commons Attribution 4.0 United States License.

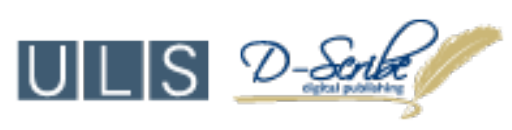

This journal is operated by the University Library System of the University of Pittsburgh as part of its D-Scribe Digital Publishing Program, and is co-sponsored by the University of Pittsburgh Press. 